\title{
Phototrophic picoplankton community structure in three different pelagic regimes in the Arabian Sea
}

\author{
Frank J. Jochem
}

Institut für Meereskunde, Düsternbrooker Weg 20, D-24105 Kiel, Germany

\begin{abstract}
Cell numbers and vertical distribution of Synechococcus, eucaryotic phototrophic picoplankton and prochlorophytes as determined by epifluorescence microscopy are presented from 3 different epipelagic systems (the mesotrophic coast off Oman, the oligotrophic central Arabian Sea and the shelf edge off Pakistan) in the Arabian Sea during the inter-monsoon period 1987. The vertical distribution patterns are described in relation to the epipelagic structure of the respective study sites. Synechococcus dominated phytoplankton in the upper mixed layer and prochlorophytes at the bottom of the euphotic zone in the lower part of and below the deep chlorophyll maximum. High pressure liquid chromatography analysis confirmed the presence of prochlorophytes and revealed vertical profiles of characteristic pigments of picoplankton organisms, chlorophyll (chl) $a$ and $b$, divinyl chl $a\left(\mathrm{chl} a_{2}\right.$ ) and zeaxanthin. Cellular pigment concentrations of Synechococcus and prochlorophytes are presented.
\end{abstract}

KEY WORDS: Picoplankton - Arabian Sea - Pigments/HPLC · Synechococcus · Prochlorophytes

It is widely recognized now that very small organisms $(<2 \mu \mathrm{m})$, so-called picoplankton, play a major role in both heterotrophic and autotrophic processes in tropical and subtropical oligotrophic ecosystems. Recent studies demonstrated the high contribution of phototrophic picoplankton $(<2 \mu \mathrm{m})$ to total productivity in the Arabian Sea (Jochem et al. 1993, Owens et al. 1993). This paper is among the first full descriptions of the picophytoplankton community in the Arabian Sea with special emphasis on the prochlorophytes. Data presented were obtained during Cruise 5, Legs 3a to 3c, of the German research vessel 'Meteor' from March to June 1987 at 3 different study sites in the Arabian Sea (Fig. 1): the Omani coast, the open oligotrophic Arabian Sea and the shelf edge off Pakistan.

Material and methods. Sampling comprised a $14 \mathrm{~d}$ drift study off the coast of Oman from March 29 to
April 11 at $21^{\circ} \mathrm{N}, 60^{\circ} \mathrm{E}$, a $14 \mathrm{~d}$ drift study (April 29 to May 12) in the central Arabian Sea at $18^{\circ} \mathrm{N}, 65^{\circ} \mathrm{E}$ and a drift study (May 22 to June 2) at the shelf edge off Pakistan at $23^{\circ} 30^{\prime} \mathrm{N}, 66^{\circ} 30^{\prime} \mathrm{E}$ (Figs. $1 \& 2$ ). During the latter, only 2 stations were sampled for picoplankton studies, and picoplankton abundance was recorded at 4 stations along a transect crossing the shelf edge (Fig. 2). Drift studies were performed by following the drift track of a drifter rig carrying sediment traps (80 to $120 \mathrm{~m}$ ) as the major friction and drag. Detailed maps of the drifter tracks are given by Jochem et al. (1993).

Water samples were taken with black 121 Niskin type water bottles. Nitrate was measured according to Grasshoff et al. (1983). Chlorophyll (chl) a was determined either trichromatically (Strickland \& Parsons 1972) and calculated after Jeffrey \& Humphrey (1975), or with a Turner Designs 10 fluorometer calibrated against trichromatically determined chl a. Another set of filters was stored frozen and was analyzed by high pressure liquid chromatography (HPLC) in the laboratory. For analysis and peak interpretation, methods of

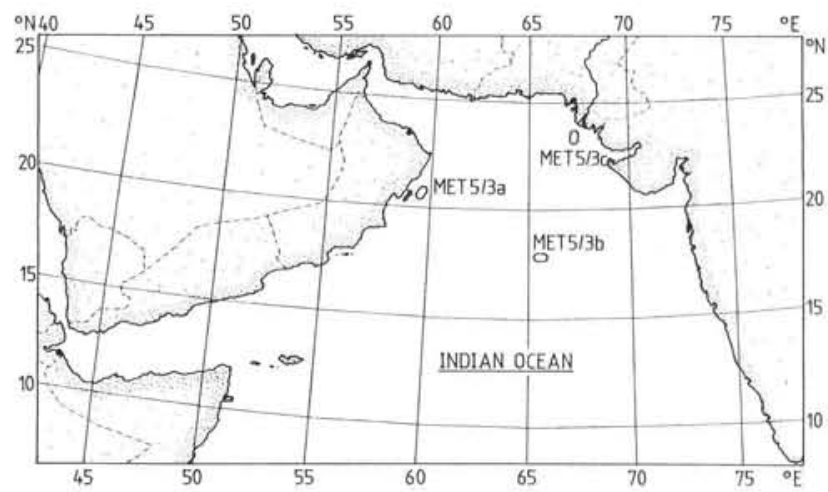

Fig. 1. Study sites in the Arabian Sea (MET5/3a to 3c) 


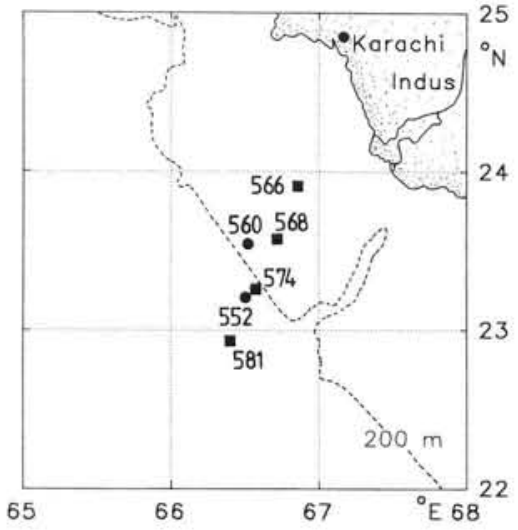

Fig. 2. Sampled stations at the shelf edge off Pakistan. $(\bullet)$ Drift study stations; ( $\mathbf{m})$ transect stations

Gieskes \& Kraay (1984) were followed including a second run of the extract for lutein/zeaxanthin separation. Divinyl chl a (chl $a_{2 i}$ Goericke \& Repeta 1992) was analyzed after Gieskes \& Kraay (1983). In situ fluorescence was recorded with a Variosens probe with analog data output.

Abundance of phototrophic picoplankton was determined by epifluorescence microscopy on black-stained $0.2 \mu \mathrm{m}$ Nuclepore filters under blue-light excitation on a Zeiss epifluorescence microscope. Samples were fil- tered without fixation and cell numbers were estimated directly afterwards in a totally dark room, since fixation and frozen storage made detection of prochlorophytes impossible. Phycoerythrin (PE)-rich cyanobacteria, cf. Synechococcus, were distinguished by their characteristic orange fluorescence. Eucaryotic phototrophic picoplankton (EPP) were defined by their pure red fluorescence and size of 0.8 to $2.0 \mu \mathrm{m}$. Prochlorophytes were defined by their weak, pure red and rapidly fading autofluorescence that was distinguished from the appearance of EPP. They exhibited a strictly spherical shape of 0.4 to $0.5 \mu \mathrm{m}$ size. For picocyanobacteria, more than 200 cells were counted, for EPP at least 50 cells, and for prochlorophytes, where detectable, more than 150 cells.

Results and discussion. The different epipelagic systems encountered at the 3 investigation sites are best seen in the vertical chl distribution which closely reflected the environmental conditions. Typical profiles for each study area are depicted in Fig. 3.

Off the coast of Oman, the chl maximum shifted from the surface to form a subsurface maximum at 40 to $80 \mathrm{~m}$ but primary production always showed surface maxima. Nitrate in surface waters was up to $0.3 \mu \mathrm{mol}$ $1^{-1}$ at the beginning of the drift (Stn 301, Day 1) but undectectable above $30 \mathrm{~m}$ after $14 \mathrm{~d}$ (Stn 391). Primary production decreased from 1.0-1.2 to less than $0.6 \mathrm{~g} \mathrm{C}$ $\mathrm{m}^{-2} \mathrm{~d}^{-1}$. Phytoplankton size structure shifted towards a higher contribution of picoplankton (Jochem et al.

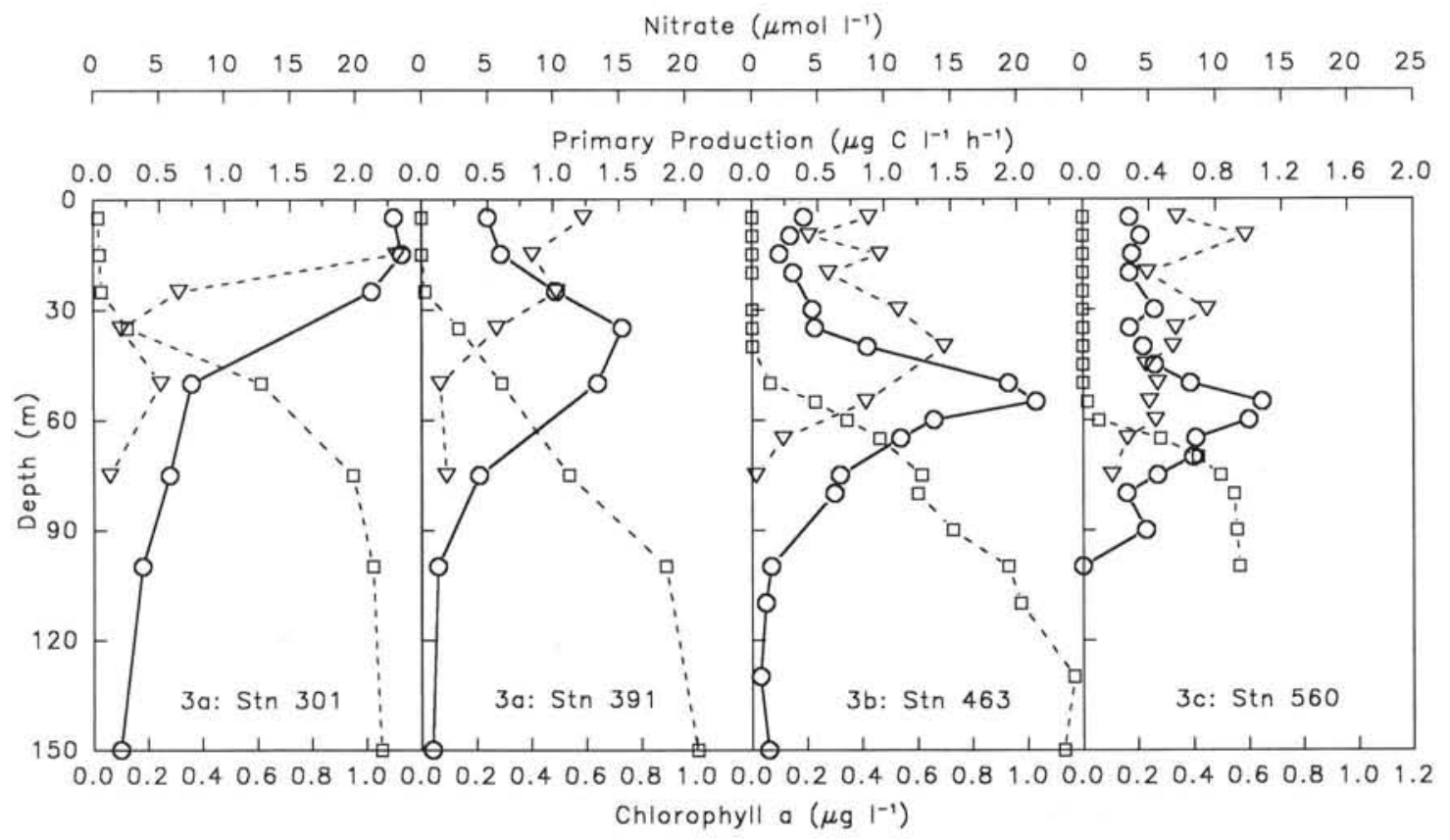

Fig. 3. Representative vertical profiles of nitrate $(\square)$, chl a (O), and primary production $(\nabla)$ of the 3 study sites: the coast of Oman (start and end of drift study; 2 left-most panels), the central Arabian Sea and the shelf edge off Pakistan 


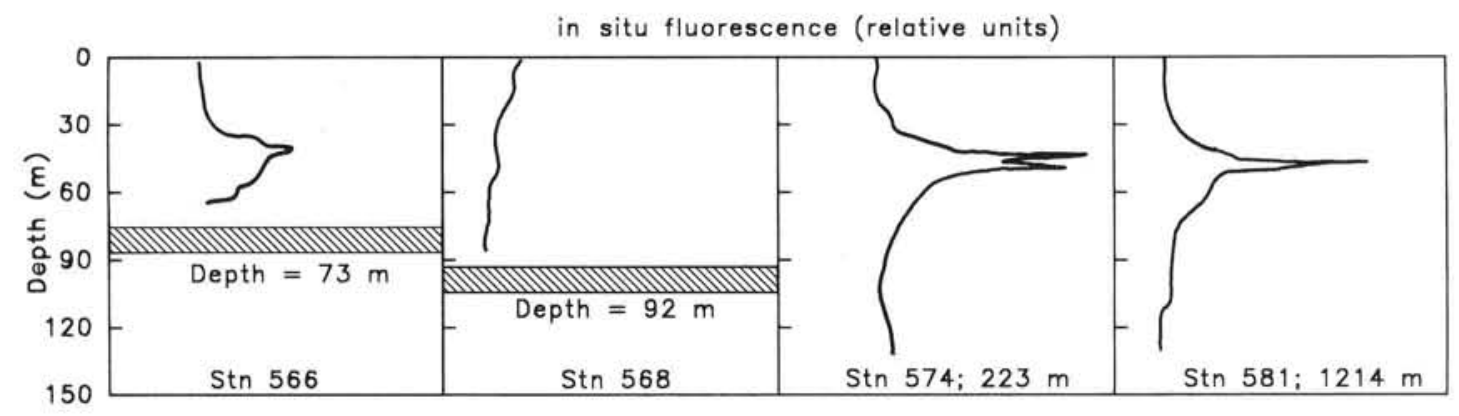

Fig. 4. Profiles of in situ chlorophyll fluorescence (relative units) along the transect crossing the shelf edge off Pakistan; hatched bars indicate bottom depths

1993), and high sedimentation rates of biogenic matter (ca $480 \mathrm{mg} \mathrm{C} \mathrm{m}^{-2} \mathrm{~d}^{-1}$ ), predominantly diatoms (Passow et al. 1993), were recorded.

The central Arabian Sea displayed the vertical structure typically known for oligotrophic oceanic provinces with a pronounced subsurface chl maximum at the nitracline and maximum primary productivity in the upper half of the subsurface maximum. Down to $40 \mathrm{~m}$, nitrate was undetectable. Production was moderate ( $\left.700 \mathrm{mg} \mathrm{C} \mathrm{m}^{-2} \mathrm{~d}^{-1}\right)$ and dominated by the picoplankton size fraction (Jochem et al. 1993). Sedimentation losses were minor (ca $24 \mathrm{mg} \mathrm{C} \mathrm{m}^{-2} \mathrm{~d}^{-1}$ ) and originated from the subsurface chl maximum (Pollehne et al. 1993).

The transect from the open ocean towards the coast of Pakistan (Fig. 2) revealed different epipelagic systems as can be seen from in situ chl fluorescence (Fig. 4). Stations off the shelf edge essentially displayed the same vertical structure as found in the central Arabian Sea. The subsurface chl maximum was less pronounced and nitrate was undetectable down to $55 \mathrm{~m}$ (Fig. 3). It was suggested that this system represented a decay stage of the 2-layered open oligotrophic ocean system; by the onset of the southwest monsoon, water masses from offshore were advected towards the shelf edge and onto the shelf. Deep nutrient-rich layers were cut off so that upward diffusion of nutrients, and subsequently primary production and phototrophic biomass, decreased (Jochem et al. 1993). Heterotrophic processes such as bacterial production (Giesenhagen 1988) and zooplankton respiration (Nellen et al. 1988) gained more importance in community dynamics. The near-shore and shallow $(73 \mathrm{~m}) \mathrm{Stn} 566$ also exhibited a subsurface chl maximum. Stn 568, however, was distinguished by its different vertical structure with a slight surface maximum that resembled provinces with high turbulence.

Phototrophic picoplankton stocks off the coast of Oman were distinguished from the other investigation areas by a pronounced surface maximum of Synechococcus even at the end of the drift period when the general structure of the epipelagic system turned towards a subsurface maximum (Fig. 5a). Maximum abundance was $2.3 \times 10^{5}$ cells ml $\mathrm{m}^{-1}$ at the beginning but 3 -fold lower at the end of the study period. EPP distribution, however, tended to have a subsurface maxima at about $20 \mathrm{~m}$ depth at the beginning of the study and 35 to $50 \mathrm{~m}$ later on; maximum cell numbers decreased from 9000 to 7000 cells ml ${ }^{-1}$. Synechococcus outnumbered EPP by a factor of 10 to 20 , sometimes 50 .

In the central Arabian Sea, vertical distribution of phototrophic picoplankton followed the general pattern of a subsurface maximum (Fig. 6). Maximum abundance of Synechococcus was 2.3 to $6.1 \times 10^{4}$ cells $\mathrm{ml}^{-1}$. Cell numbers of EPP were up to 4000 to 7000 cells $\mathrm{ml}^{-1}$. Both Synechococcus and EPP population maxima at the same depths corresponded to the upper half of the subsurface chl maximum. Below, prochlorophytes could be detected with maximum numbers of up to $5.4 \times 10^{4}$ cells ml ${ }^{-1}$ at $70 \mathrm{~m}$ depth (Fig. 6). They could not be detected by epifluorescence microscopy in samples from above $50 \mathrm{~m}$ due to weak autofluores-

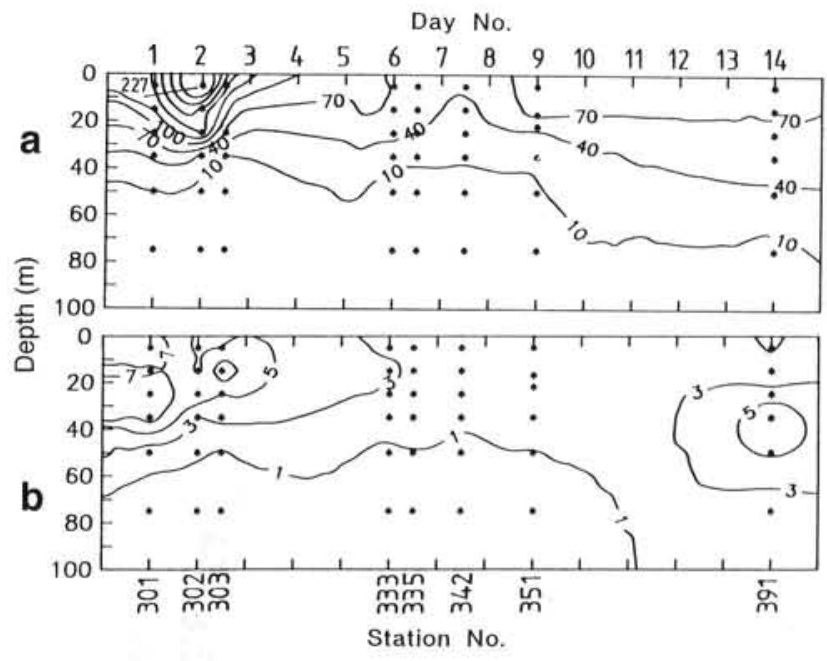

Fig. 5. Abundance $\left(10^{3}\right.$ cells $\left.\mathrm{ml}^{-1}\right)$ of (a) Synechococcus, and (b) eucaryotic phototrophic picoplankton along the drift study 


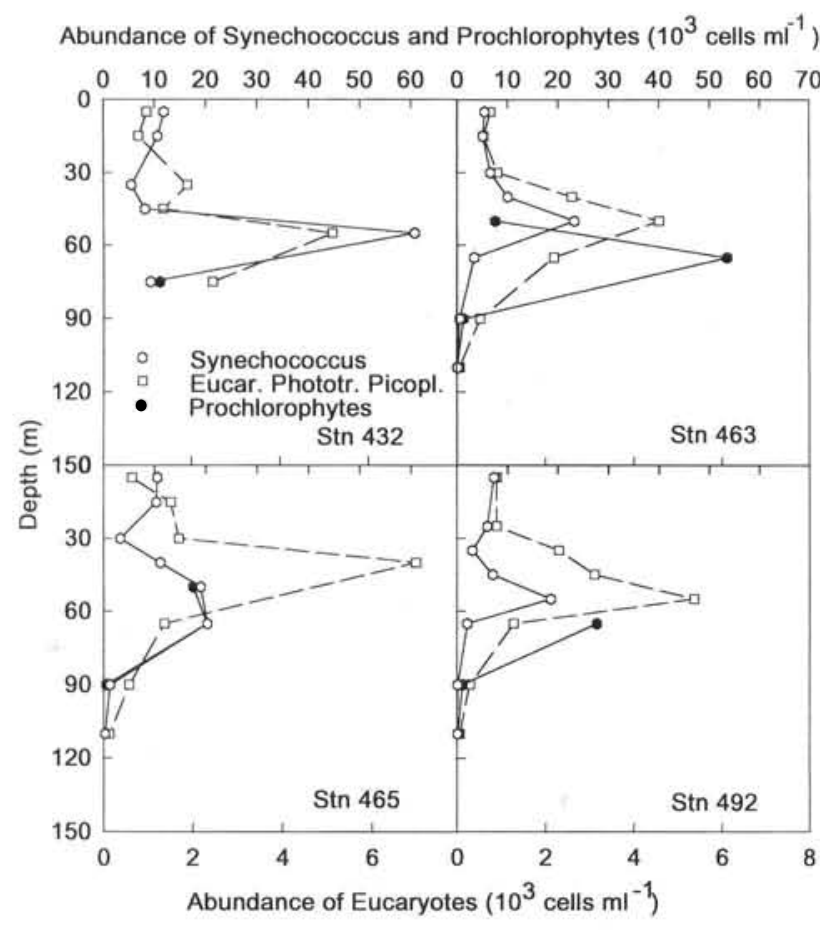

Fig. 6. Abundance of Synechococcus, eucaryotic phototrophic picoplankton, and prochlorophytes at 4 stations along the drift study in the central Arabian Sea. (Prochlorophytes only detectable in deep samples due to weak autofluorescence microscopically but may be present in shallow samples as well)

cence. It therefore is difficult to say whether the maximum cell numbers at $70 \mathrm{~m}$ depth represented their population maximum or is the effect of underestimation and the failure to detect all cells in shallow samples.
Abundance and vertical distribution of Synechococcus and EPP at the deep-water stations off the shelf edge off Pakistan were comparable to the central Arabian Sea. Both displayed subsurface maxima at 50 to $60 \mathrm{~m}$ depth (Figs. 7 \& 8). Synechococcus population maxima decreased by a factor of 3 towards the shelf (cf. Stns 581 and 560). On the shelf, the subsurface maximum was much broader and an additional surface maximum occurred (Stn 560, Fig. 7). Generally, Synechococcus outnumbered EPP by a factor of $\sim 10$. At all stations, prochlorophytes could be detected by epifluorescence microscopy in samples from below $50 \mathrm{~m}$ (Figs. $7 \& 8$ ). Cell numbers were only slightly higher at the offshore stations $\left(\leq 3.0\right.$ to $3.6 \times 10^{4}$ cells $\mathrm{ml}^{-1}$ ) than at the shelf stations $\left(\leq 2.5\right.$ to $3.1 \times 10^{4}$ cells ml $\left.^{-1}\right)$ but only two-thirds of the abundance recorded in the central Arabian Sea.

Synechococcus cell numbers recorded in the central Arabian Sea were comparable to those from other tropical regions (e.g. Joint 1986, Iturriaga \& Marra 1988, Gradinger et al. 1992, Latasa et al. 1992). Off the coast of Oman, however, they were almost 1 order of magnitude higher and in the range reported from Synechococcus spring blooms in the Sargasso Sea (Glover et al. 1988, Olson et al. 1990a), some tropical near-shore areas (Waterbury et al. 1986, Gradinger et al. 1992, Burkill et al. 1993, Veldhuis \& Kraay 1993), and some neritic temperate waters (e.g. Glover et al. 1985, Jochem 1988).

Subsurface maxima had been described as typical for Synechococcus in early reports (Li et al. 1983, Platt et al. 1983, Glover et al. 1985). Since then, surface maxima are not only known from temperate regions (El-Hag \& Fogg 1986, Jochem 1988, Kuosa 1988) but also from (sub)tropical oceans (e.g. Chisholm et al.

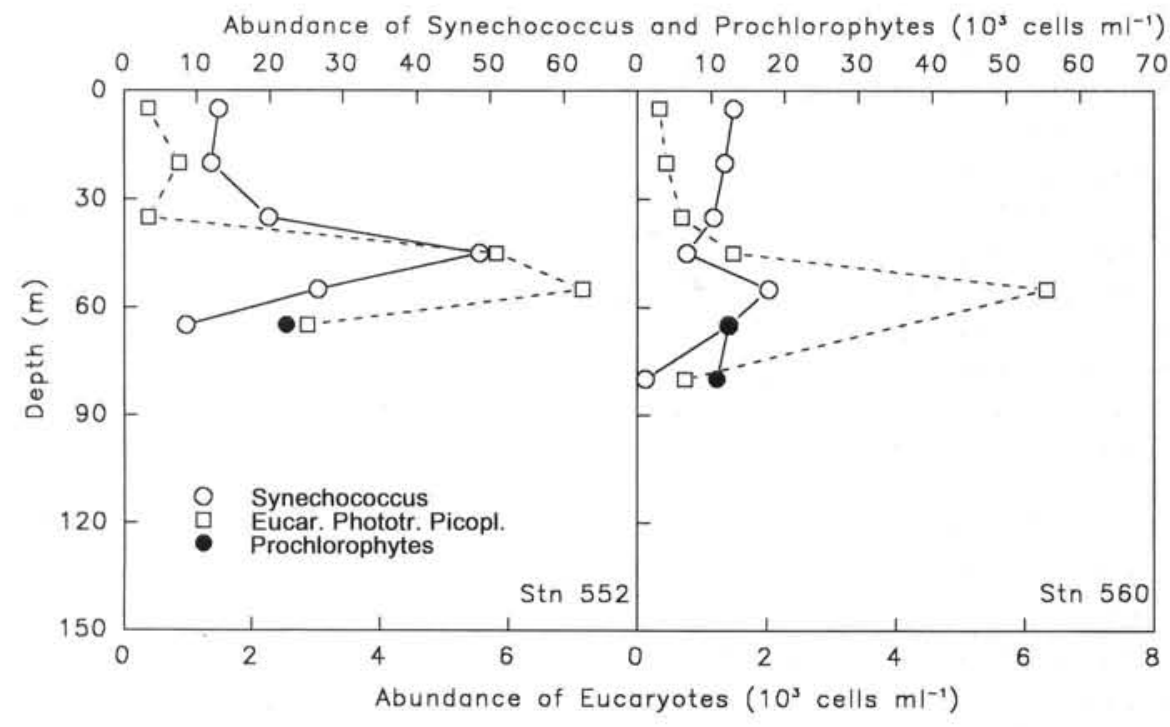

Fig. 7. Abundance of Synechococcus, eucaryotic phototrophic picoplankton, and prochlorophytes at the 2 sampled stations along the drift study at the shelf edge off Pakistan. (Prochlorophytes only detectable in deep samples due to weak autofluorescence microscopically but may be present in shallow samples as well) 
Abundance of Synechococcus and Prochlorophytes $\left(10^{3}\right.$ cells $\left.\mathrm{ml}^{-1}\right)$

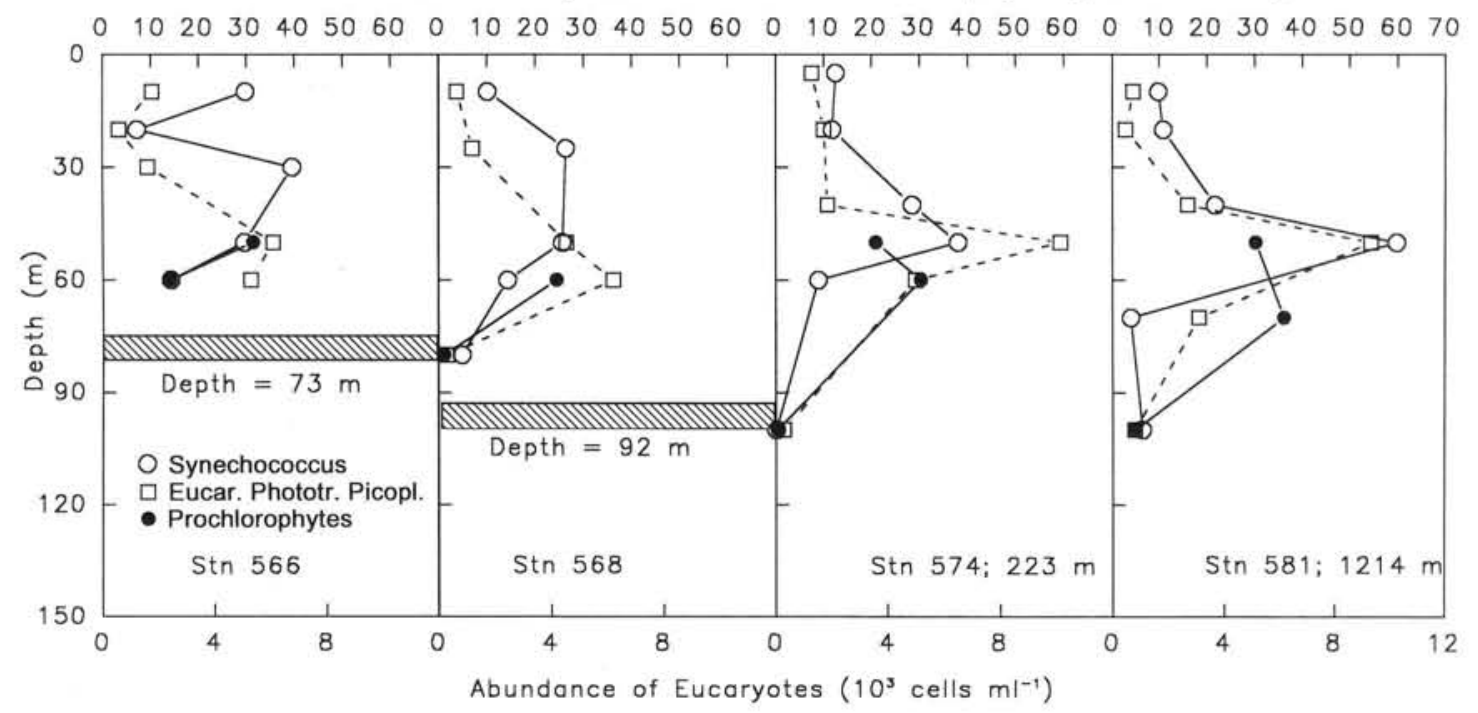

Fig. 8. Abundance of Synechococcus, eucaryotic phototrophic picoplankton, and prochlorophytes along the transect crossing the shelf edge off Pakistan; hatched bars indicate bottom depths. (Prochlorophytes only detectable in deep samples due to weak autofluorescence microscopically but may be present in shallow samples as well)

1988, Glover et al. 1988, Olson et al. 1990a, b, Veldhuis \& Kraay 1993). In the strongly stratified central Arabian Sea, Synechococcus exhibited its maximum in the upper part of the chl subsurface maximum. On the shelf off Pakistan, however, which was characterized by weak stratification, a surface maximum occurred. Surface maxima were also found off the coast of Oman. Other results from this study suggest that cold and nutrient-rich subsurface water may have been entrained into the euphotic zone (Jochem et al. 1993) as can be seen by the relatively high nitrate concentrations decreasing during the study. Despite the wellestablished stratification (thermocline at about $20 \mathrm{~m}_{\text {i }}$ Jochem et al. 1993) during the study period, the amount of nitrate at the beginning $\left(0.3 \mu \mathrm{mol}^{-1}\right.$ up to the surface) seems too high to have been entrained without recent turbulent processes. Similarily, Burkill et al. (1993) reported a change from subsurface to surface maxima along a transect towards the coast of Oman and Waterbury et al. (1986) depicted a profile with a surface maximum from the Pakistani shelf where mixing occurred down to $100 \mathrm{~m}$.

It appears that Synechococcus form surface and subsurface maxima during weak or strong water column stratification respectively. This hypothesis is further confirmed by seasonal (Iturriaga \& Marra 1988, Olson et al. 1990a) and regional (Shimada et al. 1993) studies meeting these different conditions.

Along with the consolidation of the stratification off the coast of Oman, the exhaustion of 'new' nutrients (as seen from the decrease in nitrate) and the development of a subsurface chl maximum, Synechococcus abundance also decreased but the population maximum remained at the surface. This scenario strongly resembles that shown for a spring bloom and the subsequent transition into a subsurface system in the Sargasso Sea (Olson et al. 1990a). Synechococcus obviously needs a longer time to change from surface to subsurface population growth (also in Olson et al. 1990a).

EPP abundance did not vary much between study sites (4000 to $9000 \mathrm{ml}^{-1}$ ) and was comparable to reports from the Atlantic Ocean/Sargasso Sea (Glover et al. 1985, Murphy \& Haugen 1985, Li \& Wood 1988, Li et al. 1992). They generally showed subsurface maxima in the horizon of the subsurface chl maximum as previously described (Li \& Wood 1988, Li et al. 1992, Campbell \& Vaulot 1993).

Prochlorophyte cell numbers of up to $5.4 \times 10^{4} \mathrm{ml}^{-1}$ were comparable to those measured by flow cytometry from the Atlantic Ocean/Sargasso Sea (Chisholm et al. 1988, Li \& Wood 1988, Vaulot et al. 1990, Veldhuis \& Kraay 1990, Li et al. 1992, 1993) but lower than those reported from Hawaii (Campbell \& Vaulot 1993) and the Red Sea (Veldhuis \& Kraay 1993).

By the detection of their specific chl a derivate, divinyl chl a (recently assigned chl $a_{2}$; Goericke \& Repeta 1992), HPLC analysis confirmed that small $(0.5 \mu \mathrm{m})$, red, fluorescent cells were prochlorophytes. These organisms could only be detected microscopically below $50 \mathrm{~m}$ depth due to weak autofluorescence. HPLC analysis on chl $a_{2}$ (Fig. 9a), however, proved that prochlorophytes were also present at shallower 


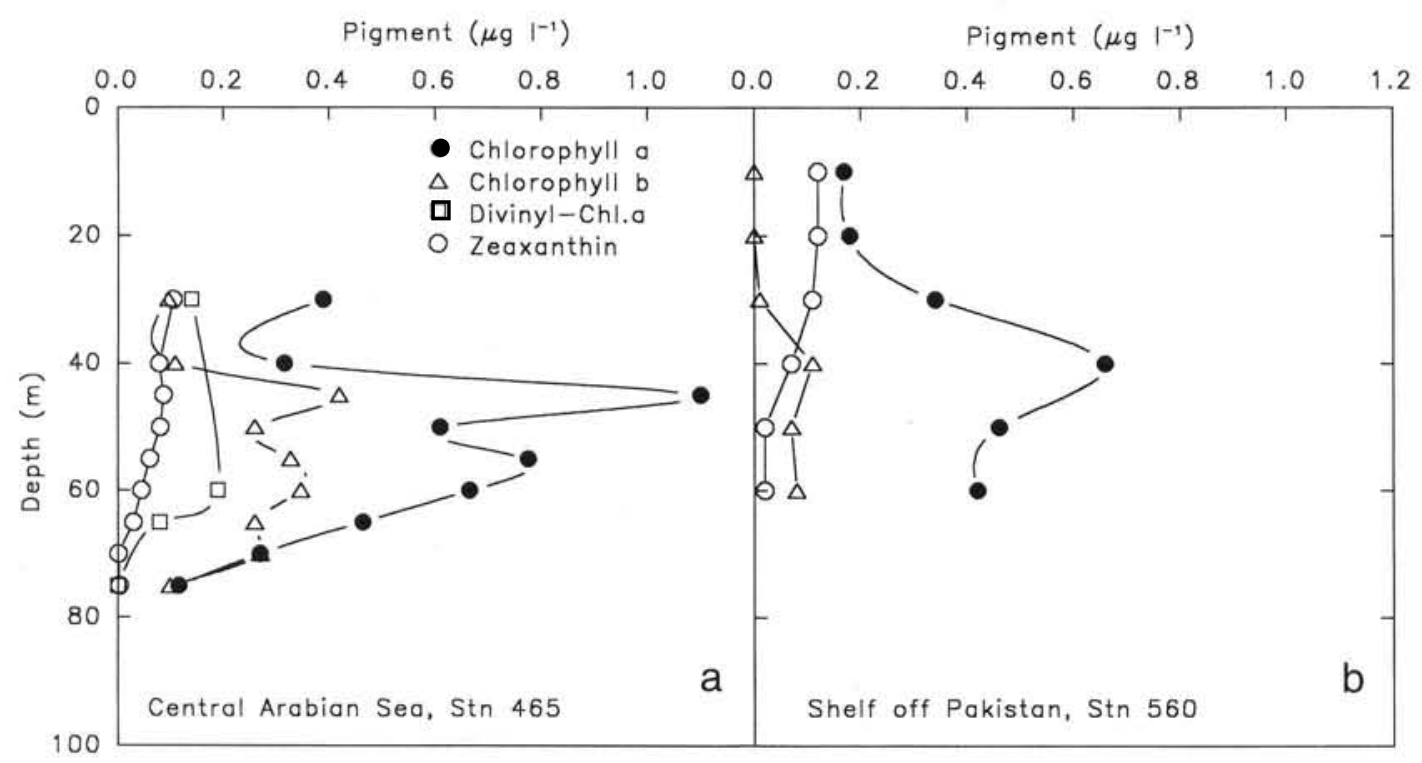

Fig. 9. Profiles of algal pigments chl $a$, divinyl-chl a ( $\left.\mathrm{chl} \mathrm{a}_{2}\right)$, chl $b$ and zeaxanthin as revealed by HPLC analysis. (a) Central Arabian Sea, Stn 465; (b) shelf edge off Pakistan, Stn 560

depths $(30 \mathrm{~m})$ in the central Arabian Sea. Concentrations at 30 and $60 \mathrm{~m}$ depth differed only slightly, 0.14 and $0.19 \mu \mathrm{g}^{-1}$ respectively. The measurements indicate a contribution of about $35 \%$ of total chl a but are too scarce for depth-dependent changes to be interpreted. Concentrations of chl $a_{2}$ were the same as measured by Gieskes \& Kraay (1986) in the subsurface chl maximum in the tropical North Atlantic $\left(20^{\circ}\right.$ $\mathrm{N}, 20^{\circ}$ to $40^{\circ} \mathrm{W}$ ) but lower than in the Red Sea (Veldhuis \& Kraay 1993).

$\mathrm{Chl} b$, present in both chlorophyta and prochlorophytes, was assigned to the latter because the absence of lutein in our samples indicated the absence of chlorophyta. Both in the central Arabian Sea and at the shelf edge off Pakistan, chl $b$ tightly followed the depth distribution of chl a (Fig. 9a, b). The occurrence of chl $b$ in the absence of lutein even in surface waters in the central Arabian Sea indicates the presence of prochlorophytes up to the surface. At the shelf edge off Pakistan, chl b was, however, undetectable above $30 \mathrm{~m}$ depth. Lower chl $b$ concentrations here as compared to the central Arabian Sea are concomitant with lower prochlorophyte cell numbers. No chl $a_{2}$ analyses were performed at this station.

At both stations, zeaxanthin, present in Synechococcus and prochlorophytes, did not reflect the subsurface maxima of these organisms. Thus, cellular concentration of zeaxanthin cannot be constant for either of them as described for Synechococcus by Kana et al. (1988) but decreases with depth. This is in agreement with zeaxanthin seen as photoprotective pigment (Gieskes \& Kraay 1986, Latasa et al. 1992).
The combination of picophytoplankton enumeration and HPLC pigment analysis enabled the calculation of cellular pigment contents of Synechococcus and prochlorophytes, where microscopically detectable. In samples with both Synechococcus and prochlorophytes, cellular concentration of zeaxanthin was calculated assuming the same pigment/volume ratio and mean cell diameters of $1.2 \mu \mathrm{m}$ and $0.5 \mu \mathrm{m}$ respectively.

Cellular concentrations of zeaxanthin in Synechococcus from subsurface layers $\left(0.6\right.$ to $\left.3.3 \mathrm{fg} \mathrm{cell}^{-1}\right)$ were comparable to literature values $\left(1.81 \mathrm{fg} \mathrm{cell}^{-1}\right.$, Kana et al. $1988 ; 2.0$ to $3.6 \mathrm{fg} \mathrm{cell}^{-1}$, Latasa et al. 1992). Estimated 2.8 to $7.9 \mathrm{fg}$ cell $^{-1}$ in surface layer samples are, however, above the published range and might result from the underestimation of the prochlorophyte share to zeaxanthin in shallow samples.

Cellular zeaxanthin concentrations of prochlorophytes of 0.1 to $0.6 \mathrm{fg} \mathrm{cell}^{-1}$ were lower than reported in the literature (Table 1) except for Chisholm et al. (1988) and Partensky et al. (1993). The high $1.97 \mathrm{fg}$ cell $^{-1}$ of Veldhuis \& Kraay (1990) was, however, calculated by the authors assuming a constant pigment content of the co-occurring Synechococcus of $1.81 \mathrm{fg} \mathrm{cell}^{-1}$ given by Kana et al. (1988). The values of Goericke \& Repeta (1992) are from cultures and may be different from in situ populations as cultivation often leads to physiological changes, whereas those of Vaulot et al. (1990) are derived from surface populations in the northwestern Mediterranean. The cellular concentrations of chl $a_{2}\left(1.5 \mathrm{fg} \mathrm{cell}^{-1}\right)$ and chl $b$ (2.2 to $5.7 \mathrm{fg}$ cell $^{-1}$ ) are well within the range of published values (Table 1). 
Table 1. Published cellular pigment content of prochlorophytes (fg pigment cell ${ }^{-1}$ )

\begin{tabular}{|c|c|c|c|c|}
\hline Source & Region & Chl $a_{2}$ & $\mathrm{Chl} b$ & Zeaxanthin \\
\hline Chisholm et al. (1988) & Sargasso Sea & 2.15 & 2.31 & 0.69 \\
\hline Neveux et al. (1989) & NW Mediterranean Sea & 1.9 & & \\
\hline Vaulot et al. (1990) & NW Mediterranean Sea & 2.1 & $0.48^{\mathrm{a}}$ & $2.35^{\mathrm{a}}$ \\
\hline Veldhuis \& Kraay (1990) & $\begin{array}{l}\text { Atlantic Ocean } 33^{\circ}-37^{\circ} \mathrm{N}, 20^{\circ} \mathrm{W} \\
\text { Surface } \\
0.3 \% \text { light level }\end{array}$ & $\begin{array}{l}0.91 \\
5.4\end{array}$ & $\begin{array}{l}0.44 \\
8.2\end{array}$ & $1.97^{b}$ \\
\hline Goericke \& Repeta (1992) & Cultures & 3.11 & 3.56 & 2.15 \\
\hline Partensky et al. (1993) & $\begin{array}{l}\text { Cultures } \\
\text { Mediterranean isolate } \\
\text { Sargasso Sea isolate } \\
\text { North Atlantic isolate }\end{array}$ & $\begin{array}{l}1.21-4.26 \\
1.12-2.82 \\
1.84-3.50\end{array}$ & $\begin{array}{l}0.11-0.57 \\
0.59-4.56 \\
0.75-3.11\end{array}$ & $\begin{array}{l}0.35-0.84 \\
0.53-0.80 \\
0.64-0.95\end{array}$ \\
\hline Veldhuis \& Kraay (1993) & $\begin{array}{l}\text { Red Sea } \\
\text { Arabian Sea, Somali upwelling }\end{array}$ & 2.45 & $\begin{array}{l}0.08-2.38 \\
2.63^{c}\end{array}$ & $0-4.49^{c}$ \\
\hline 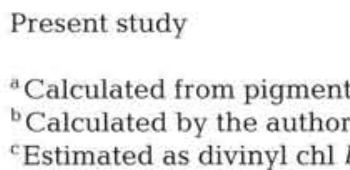 & $\begin{array}{l}\text { Arabian Sea } \\
\text { os given by the authors } \\
\text { uming constant cellular pigment }\end{array}$ & 1.49 & $\begin{array}{l}2.2-5.7 \\
\text { fg cell }\end{array}$ & $0.1-0.6$ \\
\hline
\end{tabular}

The shape of microscopically derived profiles often looks like those in the early prochlorophyte studies and obviously only the lower part of their distribution was detected. Whereas some studies showed the prochlorophyte maximum below that of Synechococcus (Chisholm et al. 1988, Olson et al. 1990a), others report it above the subsurface chl maximum (Neveux et al. 1989) just above the nitracline (Veldhuis \& Kraay 1990, Shimada et al. 1993, Veldhuis et al. 1993). From the present study the prochlorophyte maximum appears below that of Synechococcus in the lower half of the subsurface chl maximum. Prochlorophytes contribute as much as or even more phototrophic biomass than Synechococcus and presumably a major part of the primary production at the bottom of the euphotic zone (Jochem et al. 1993). Further studies by HPLC analysis and high sensitivity flow cytometry have to confirm the regional and vertical distribution of prochlorophytes in the Arabian Sea, as well as the failure to detect them off the coast of Oman while considerable numbers were found off Pakistan. Combination of HPLC pigment analysis and shipboard flow cytometry sorting have to confirm cellular pigment content and its variability.

Acknowledgements. I thank the captain and crew of the RV 'Meteor', as well as all my colleagues involved in this cruise, for their efficient help at sea. Nitrate measurements by Rolf Werner and Peter Fritsche are greatly appreciated. I am grateful to Falk Pollehne and Albert Klein for HPLC analysis data. This work was funded by DFG grants Ne-99/21 and Ze-119/10.

\section{LITERATURE CITED}

Burkill, P. H., Leakey, R. J. G., Owens, N. J. P., Mantoura, R. F. C. (1993). Synechococcus and its importance to the microbial foodweb of the northwestern Indian Ocean. Deep Sea Res. 40: 773-782

Campbell, L., Vaulot, D. (1993). Photosynthetic picoplankton community structure in the subtropical North Pacific Ocean near Hawaii (station ALOHA). Deep Sea Res. 40: 2043-2060

Chisholm, S. W., Olson, R. J., Zettler, E. R., Goericke, R., Waterbury, J. B., Welschmeyer, N. A. (1988). A novel freeliving prochlorophyte abundant in the oceanic euphotic zone. Nature 334: 340-342

El-Hag, A. G. D., Fogg, G. E. (1986). The distribution of coccoid blue-green algae (Cyanobacteria) in the Menai Straits and the Irish Sea. Br. Phycol. J. 21: 45-54

Giesenhagen, H. (1988). Zur Verteilung heterotropher Aktivität und bakterieller Sekundärproduktion im Küstenbereich des Arabischen Meeres zum Beginn des SüdwestMonsuns. Diplom thesis, Kiel University

Gieskes, W. W. C., Kraay, G. W. (1983). Unknown chlorophyll a derivates in the North Sea and the tropical Atlantic Ocean revealed by HPLC analysis. Limnol. Oceanogr. 28: $757-766$

Gieskes, W. W. C., Kraay, G. W. (1984). Phytoplankton, its pigments and primary production at a central North Sea station in May, July and September 1981. Neth. J. Sea Res. 18: $51-70$

Gieskes, W. W. C., Kraay, G. W. (1986). Floristic and physiological differences between the shallow and the deep nanophytoplankton community in the euphotic zone of the open tropical Atlantic revealed by HPLC analysis of pigments. Mar. Biol. 91: 567-576

Glover, H. E., Phinney, D. A., Yentsch, C. S. (1985). Photosynthetic characteristics of picoplankton compared with those of larger phytoplankton populations in various water masses in the Gulf of Maine. Biol. Oceanogr. 3: 223-248 
Glover, H. E., Prézelin, B. B., Campbell, L., Wyman, M., Garside, C. (1988). A nitrate-dependent Synechococcus bloom in surface Sargasso Sea water. Nature 331: 161-163

Goericke, R., Repeta, D. J. (1992). The pigments of Prochlorococcus marinus: the presence of divinyl chlorophyll $a$ and $b$ in a marine procaryote. Limnol. Oceanogr. 37: 425-433

Gradinger, R., Weisse, T., Pillen, T. (1992). Significance of picocyanobacteria in the Red Sea and the Gulf of Aden. Botanica mar. 35: 245-250

Grasshoff, K., Ehrhardt, M., Kremling, K. (1983). Methods of seawater analysis. Verlag Chemie, Weinheim

Iturriaga, R., Marra, J. (1988). Temporal and spatial variability of chroococcoid cyanobacteria Synechococcus spp. specific growth rates and their contribution to primary production in the Sargasso Sea. Mar. Ecol. Prog. Ser. 44: $175-181$

Jeffrey, S. W., Humphrey, G. F. (1975). New spectrophotometric equations for determining chlorophylls $a, b, c_{1}, c_{2}$ in higher plants and phytoplankton. Biochem. Physiol. Pflanz. 167: 191-194

Jochem, F. J. (1988). On the distribution and significance of picocyanobacteria in a boreal inshore area (Kiel Bight, Western Baltic). J. Plankton Res. 10: 1009-1022

Jochem, F., Pollehne, F., Zeitzschel, B. (1993). Productivity regime and phytoplankton size structure in the Arabian Sea. Deep Sea Res. 40: 711-736

Joint, I. R. (1986). Physiological ecology of picoplankton in various oceanographic provinces. In: Platt, T., Li, W. K. W. (eds.) Photosynthetic picoplankton. Can. Bull. Fish. Aquat. Sci. 214: 287-309

Kana, T. M., Glibert, P. M., Goericke, R., Welschmeyer, N. A. (1988). Zeaxanthin and $\beta$-carotene in Synechococcus WH7803 respond differently to irradiance. Limnol. Oceanogr. 33: 1623-1627

Kuosa, H. (1988). Occurrence of autotrophic picoplankton along an open sea-inner archipeligo gradient in the Gulf of Finland, Baltic Sea. Ophelia 28: 85-93

Latasa, M., Estrada, M., Delgado, M. (1992). Plankton-pigment relationships in the northwestern Mediterranean during stratification. Mar. Ecol. Prog. Ser. 88: 61-73

Li, W. K. W., Dickie, P. M., Irwin, B. D., Wood, A. M. (1992). Biomass of bacteria, cyanobacteria, prochlorophytes and photosynthetic eukaryotes in the Sargasso Sea. Deep Sea Res. 39: 501-519

Li, W. K. W., Dickie, P. M., Harrison, W. G., Irwin, B. D. (1993). Biomass and production of bacteria and phytoplankton during the spring bloom in the western North Atlantic Ocean. Deep Sea Res. 40: 307-327

Li, W. K. W., Subba Rao, D. V., Harrison, W. G., Smith, J. C. Culler, J. J., Irwin, B., Platt, T. (1983). Autotrophic picoplankton in the tropic ocean. Science 219: 292-295

Li, W. K. W., Wood, A. M. (1988). Vertical distribution of North Atlantic ultraphytoplankton: analysis by flow cytometry and epifluorescence microscopy. Deep Sea Res. 35: 1615-1638

Murphy, L. S., Haugen, E. M. (1985). The distribution and abundance of phototrophic ultraplankton in the North Atlantic. Limnol. Oceanogr. 30: 47-58

Nellen, W., Schnack, D., Zeitzschel, B. (1988). Expeditionsbericht über die Meteor-Reise Nr. 5 Abschnitt 3. Berichte aus dem Zentrum für Meeres- und Klimaforschung der

This note was submitted to the editor
Universität Hamburg, Hamburg

Neveux, J. D., Vaulot, D., Courties, C., Fukai, E. (1989). Green photosynthetic bacteria associated with the deep chlorophyll maximum of the Sargasso Sea. C.r. Acad. Sci., Paris Sér. III 308: 9-14

Olson, R. J., Chisholm, S. W., Zettler, E. R., Altabet, M. A., Dusenberry, J. A. (1990a). Spatial and temporal distributions of prochlorophyte picoplankton in the North Atlantic Ocean. Deep Sea Res. 37: 1033-1051

Olson, R. J., Chisholm, S. W., Zettler, E. R., Armbrust, E. V. (1990b). Pigments, size, and distribution of Synechococcus in North Atlantic and Pacific Oceans. Limnol. Oceanogr. 35: $45-58$

Owens, N. J. P., Burkill, P. H., Mantoura, R. F. C., Woodward, E. M. S., Bellan, I. E., Aiken, J., Howland, R. J. M., Llewellyn, C. A. (1993). Size-fractionated primary production and nitrogen assimilation in the northwestern Indian Ocean. Deep Sea Res. 40: 697-710

Partensky, F., Hoepffner, N., Li, W. K. W., Ullosa, O., Vaulot, D. (1993). Photoacclimation of Prochlorococcus sp. (Prochlorophyta) strains isolated from the North Atlantic and the Mediterranean Sea. Plant Physiol. 101: 285-296

Passow, U., Peinert, R., Zeitzschel, B. (1993). Distribution and sedimentation of organic matter during the inter-monsoon period off Oman (West Arabian Sea). Deep Sea Res. 40: 833-849

Platt, T., Subba Rao, D. V., Irwin, B. (1983). Photosynthesis of picoplankton in the oligotrophic ocean. Nature 301: 702-704

Pollehne, F., Zeitzschel, B., Peinert, R. (1993). Short-term sedimentation patterns in the northern Indian Ocean. Deep Sea Res. 40: 821-832

Shimada, A., Hasegawa, T., Umeda, I., Kadoya, N., Maruyama, T. (1993). Spatial mesoscale patterns of West Pacific picophytoplankton as analyzed by flow cytometry: their contribution to subsurface chlorophyll maxima. Mar. Biol. 115: 209-215

Strickland, J. H., Parsons, T. R. (1972). A practical handbook of seawater analysis, 2nd edn. Bull. Fish. Res. Bd Can. 167

Vaulot, D., Partensky, F., Neveux, J., Mantoura, R. F. C., Llewellyn, C. A. (1990). Winter presence of prochlorophytes in surface waters of the northwestern Mediterranean Sea. Limnol. Oceanogr. 35: 1156-1163

Veldhuis, M. J. W., Kraay, G. W. (1990). Vertical distribution and pigment composition of a picoplanktonic prochlorophyte in the subtropical North Atlantic: a combined study of HPLC analysis and flow cytometry. Mar. Ecol. Prog. Ser. 68: $121-127$

Veldhuis, M. J. W., Kraay, G. W. (1993). Cell abundance and fluorescence of picoplankton in relation to growth irradiance and nitrogen availability in the Red Sea. Neth. J. Sea Res. 31: 135-145

Veldhuis, M. J. W., Kraay, G. W., Gieskes, W. W. C. (1993). Growth and fluorescence characteristics of ultraplankton on a north-south transect in the eastern North Atlantic. Deep Sea Res. 40: 609-626

Waterbury, J. B., Watson, S. W., Valois, F. W., Franks, D. G. (1986). Biological and ecological characterization of the marine unicellular cyanobacterium Syncheococcus. In: Platt, T., Li, W. K. W. (eds.) Photosynthetic picoplankton. Can. Bull. Fish. Aquat. Sci. 214: 71-120

Manuscript first received: July 15, 1994

Revised version accepted: September 29, 1994 